УДК 624.014.2.004

ОЦІНКА НАДІЙНОСТІ ЗАЛІЗОБЕТОННИХ БАЛОК, ЩО ЗАЗНАЮТЬ ДІЇ МАЛОЦИКЛОВИХ ПОВТОРНИХ І ЗНАКОЗМІННИХ НАВАНТАЖЕНЬ

\author{
Канд. техн. наук Г. Х. Масюк (НУВГП)
}

ОЦЕНКА НАДЕЖНОСТИ ЖЕЛЕЗОБЕТОННЫХ БАЛОК ПРИ ДЕЙСТВИИ

МАЛОЦИКЛОВЫХ ПОВТОРНЫХ И ЗНАКОПЕРЕМЕННЫХ НАГРУЗОК

Канд. техн. наук Г. Х. Масюк (НУВХП)

\title{
ASSESSMENT OF RELIABILITY OF REINFORCED CONCRETE BEAMS IN ACTION OF SMALL-CYCLE REPEATS AND VARIABLE LOADS
}

\section{Candidate of technical sciences G. Ch. Masjuk}

Використовуючи експериментальні дані, виконано приклад розрахунку оцінки надійності залізобетонних балок за дї малочиклових повторних $i$ знакозмінних навантажень. При визначенні оцінки надійності балок було використано існуючу методику розрахунку надійності будівельних конструкцій при дї одноразових статичних навантажень.

Ключові слова: залізобетонні балки, малоциклові знакозмінні навантаження, надійність, випадкові величини.

Используя экспериментальные данные, выполнен пример расчета оценки надежности железобетонных балок при действии малоиикловых повторяемых и знакопеременных нагрузок. При определении оценки надежности балок была использована методика расчета надежности строительных конструкиий при действии однократных статических нагрузок.

Ключевые слова: железобетонные балки, малоцикловые знакопеременные нагрузки, надежность, случайные величины.

Example of calculating the reliability assessment of reinforced concrete beams under the actions repeated small cycle loads who work in different axis using experimental data. The estimates of beams reliability was used like the method of calculating the reliability of building structures under the action of single static loads. The difference between stress-strain state of reinforced concrete structures for the repeated cyclic bending action and stress-strain state of reinforced concrete beams under the long influence unambiguous static load was compare by experimental and theoretical research. Under the action of repeated cyclic alternating loads : 
beams carrying capacity is reduced by 5 to 25 percent; bending moment of crack appearance decrease threefold and the width of crack increased. Expose of that action influence depends of stress level and grade of concrete. Taking into account changes in the stress-strain state of the beams for action was repeated cyclic alternating loads covered in the issued recommendations. Since the parameters deflected mode of change be it the need to assess the reliability of such beams.

Keywords: reinforced concrete beams, small cycle loads, reliability, random variables.

Вступ. Досвід будівництва й експлуатації засвідчує, що однакові будівлі й споруди, які будуються та експлуатуються в аналогічних умовах, або їхні окремі конструктивні елементи виходять із ладу в різні випадкові моменти, тобто не можна точно визначити термін служби будівельної конструкції, а можна лише оцінити ту ймовірність, 3 якою буде експлуатуватися ця будівля чи споруда протягом заданого періоду. Тому в методах оцінки надійності необхідна інформація про змінність параметрів навантажень, міцність будівельних матеріалів, як випадкових величин, відхилень від розрахункових моделей i т. п. Із указаних факторів навантаження i його дії являють собою найбільш невизначені величини, що мають великі статичні розкиди. У питаннях надійності будівельних конструкцій вивчення мінливості режимів навантажень відіграє при цьому головну роль.

Аналіз останніх досліджень i публікацій. Ще в 40-50-ті роки минулого сторіччя ряд зарубіжних $\mathrm{i}$ вітчизняних учених приділяли увагу проблемі безпечності будівельних конструкцій, у яких як випадкові величини використовувались не тільки міцнісні характеристики матеріалів, а й параметри навантажень. Авторами робіт у ті часи 3 цієї проблеми були М. С. Стрілецький, В. Вержбицький, М. Плот, О. Р. Ржаніцин та ін. Дещо пізніше з проблеми надійності будівельних конструкцій проводили фундаментальні дослідження такі науковці, як В. В. Болотін, О.С. Личев, С.А. Тімашов, Ю.Д. Сухов і багато інших. Значний внесок у вирішення проблеми надійності будівельних конструкцій, будівель і споруд зробили у своїх роботах В. Д. Райзер $[1,2]$,
А. В. Перельмутер [3-5]. На сьогоднішній день проблемі розрахунків будівельних конструкцій на надійність присвячені роботи таких науковців, як С. Ф. Пічугін i його школа [6-10], P. I. Кінаш [11], С. Б. Усаковський [12], Ditlevsen, O. D., Der Kiureghian, A, Song, J. [13] та ін.

Мета і задачі досліджень. Визначити оцінку надійності залізобетонних балок за дії малоциклових повторних і знакозмінних навантажень на основі експериментальнотеоретичних досліджень.

Основна частина тексту. Діючі нормативні документи $[14,15]$ у розрахунках залізобетонних конструкцій не враховують передісторію їх завантажень. Хоча в процесі експлуатації ряд конструкцій зазнають дії малоциклових повторних i знакозмінних навантажень i напружено-деформований стан їх суттєво відрізняється від н.д.с. конструкцій, що зазнають дії одноразових статичних навантажень. До конструкцій, що зазнають дії знакозмінних навантажень різної інтенсивності, слід віднести: багатопрогонові нерозрізні балки перекриття будівель, колони крайнього ряду промислових будівель, підкранові балки, опори ЛЕП, захисні оболонки АЕС, стояки потужних вітрогенераторних установок і кранових естакад, будівель в аварійних ситуаціях i т.п. Такі навантаження можуть створюватися вітровими, сейсмічними, технологічними діями, впливами попереднього напруження.

У лабораторії кафедри промислового, цивільного будівництва та інженерних споруд аспірантами безпосередньо під керівництвом автора було випробувано 57 залізобетонних балок, що зазнавали дії малоциклових повторних $\mathrm{i}$ знакозмінних 
навантажень різної інтенсивності. Балки розмірами 100x160x2000 мм виготовлено із бетонів класів C16/20, C25/30, 30/35 і армовано двома каркасами. Армування перерізу подвійне, симетричне. Як робоча арматура використовувалась арматура класів A400 і А500C діаметром 10, 12, 14 мм. Поперечна арматура використовувалась із класу В500.

Балки випробовувались за схемою «чистого згину» у віці 30 діб і старшому. Зосереджені сили прикладались у третинах прогону ступінчастим навантаженням, приріст приймався рівним $0,1 \mathrm{M}_{\mathrm{u}}\left(\mathrm{M}_{\mathrm{u}}\right.$ руйнівний згинальний момент за однозначного навантаження). За цією схемою навантажень досліджувалась робота i напружено-деформований стан нормальних i похилих перерізів. Режими малоциклових повторних i знакозмінних навантажень і їх характер для різних балок були різних рівнів і змінювалися від 0,2 до 0,8. Експериментальні дослідження проводились у спеціальних дослідних установках, що давало змогу створювати знакозмінні навантаження в балках без зміни їх положення.

Аналіз експериментальних досліджень показав, що знакозмінні малоциклові навантаження знижують несучу здатність балок на 6...25\% порівняно 3 балками, які зазнавали впливу короткочасного одноразового ступеневого навантаження до руйнування. Діапазон зниження несучої здатності балок залежить від характеру режимів і рівнів завантаження. Балки випробовувались 10-цикловими знакозмінними навантаженнями (завантаження до певного рівня, розвантаження, завантаження до певного рівня другим знаком, розвантаження - 1 цикл). Найменшу несучу здатність мали балки, що зазнавали дії знакозмінного навантаження рівнів $\eta=0,65 / 0,8 \mathrm{Fu}$, тобто балки, які довантажувались на 5-му циклі до $\eta=0,8 \mathrm{Fu}$.
Руйнування балок відбувалося в основному по нормальних перерізах унаслідок досягнення в робочій арматурі умовної межі текучості.

Вірогідно основною причиною зниження несучої здатності балок, що зазнавали дії малоциклового знакозмінного навантаження, $€$ порушення структури бетону, тобто порушення його ізотропних якостей у поздовжньому i поперечному напрямах, що призводить до зменшення зчеплення арматури з бетоном.

Слід зазначити, що клас бетону, 3 якого виготовлялися дослідні балки, суттєво впливає на їх роботу за дії малоциклових знакозмінних навантажень. Із зниженням класу бетону в перерізах балок більш інтенсивно проходять деструктивні процеси - у результаті чого різко збільшуються деформації $\mathrm{i}$ напруження в робочій арматурі та знижується несуча здатність.

На основі вищевикладеного визначимо оцінку надійності балок, що зазнають дії малоциклових знакозмінних навантажень на основі числового прикладу. Для розрахунку надійності візьмемо балки 3 найменшою несучою здатністю (середнє значення несучої здатності 20 балок).

Числовий приклад. Вихідні дані балка має переріз 3 розмірами $\mathrm{bxh}=100 \mathrm{x} 160 \mathrm{мм} ; \quad \alpha=15 \mathrm{Mм} ; \quad \alpha^{\prime}=15 \mathrm{Mм} ;$ армування подвійне по два стержні ф10 із класу A400 $\left(\mathrm{A}_{\mathrm{s}}=\mathrm{A}_{\mathrm{s}}^{\prime}=1,57 \quad \mathrm{~cm}^{2}\right), \mathrm{f}_{\mathrm{yd}}=\mathrm{f}_{\mathrm{yd}}^{\prime}=$ = 365 МПа; бетон класу C16/20 ( $\left.\mathrm{f}_{\mathrm{cd}}=11,5 \mathrm{MПа}\right)$. Розрахунковий момент $\quad \mathrm{M}_{\mathrm{u} \ell \mathrm{t}}=7,6 \mathrm{\kappa HM}$ (взятий із даних випробовуваних балок.)

Оцінюємо надійність балки за методикою, викладеною в [10], 3 дотриманням ДБН [16].

\section{1. Статистичні характеристики} матеріалів. Визначаємо їх за розрахунковими характеристиками:

- бетон C16/20

- математичне сподівання:

$$
\bar{\sigma}_{\mathrm{C}}=\frac{f_{\mathrm{cd}}}{1-1,64 \cdot \mathrm{V}}=11, \frac{5}{1-1,64 \cdot 0,135}=14,76 \mathrm{M \Pi a}=1,48 \frac{\mathrm{kH}}{\mathrm{cm}^{2}}
$$


- стандарт (коефіцієнт варіації $\left.\mathrm{V}_{\mathrm{c}}=0,135\right)$;

- арматура A400

- математичне сподівання:

$$
\frac{\bar{\sigma}_{\mathrm{sc}}=f_{\mathrm{y}}}{=25}, 0 \frac{\mathrm{kH}}{\mathrm{cm}^{2}}
$$$$
\text { дані } \quad 3
$$

експериментальних досліджень;

$$
\begin{aligned}
& \text { - сандарт } \quad \text { (коефіцієнт } \quad \text { варіації } \\
& \left.\mathrm{V}_{\mathrm{s}}=0,0436\right) \text {. }
\end{aligned}
$$

Коефіцієнти варіації $\mathrm{V}_{\mathrm{c}}$ i $\mathrm{V}_{\mathrm{s}}$ взято 3 табл. 2,31 [10].

2. Числові характеристики граничного моменту. За наведеною формулою обчислюємо математичне сподівання граничного моменту:

$$
\bar{M}_{u l t}=\bar{\sigma}_{s} A_{s} \cdot d-\bar{\sigma}_{S C} \cdot A_{S}^{\prime} \cdot a^{\prime}-0,5 \cdot \frac{\left(\bar{\sigma}_{s} A_{g}-\bar{\sigma}_{S C} \cdot A_{s}\right)^{2}}{\bar{\sigma}_{c}-b}=40 \cdot 1,57 \cdot 14,5-25 \cdot 1,57 \cdot 1,5-\frac{0,5}{14,76 \cdot 10}(40 \cdot 1,57-25 \cdot 1,57)=851,72 \mathrm{KHCM}=8,52 \mathrm{KH}
$$

Визначимо коефіцієнт для обчислення стандарту граничного моменту.

$$
\begin{aligned}
& D_{s c}=\frac{\partial \bar{M}_{u l t}}{\partial \sigma_{s}}=\frac{A_{s}}{\bar{\sigma}_{c} b}\left[\bar{\sigma}_{c} d b\left(\bar{\sigma}_{s} A_{s}-\bar{\sigma}_{s c} \cdot A_{s}^{\prime}\right)\right]==\frac{1,57}{1,480 \cdot 10}(1,48 \cdot 14,5 \cdot 10-40 \cdot 1,57+25 \cdot 1,57)=20,27 \mathrm{~cm}^{2} \\
& D_{s c}=\frac{\partial \bar{M}_{u l t}}{\partial \sigma_{c s}}=\frac{A_{s}}{\bar{\sigma}_{c} b}\left[-\bar{\sigma}_{c} b \cdot a^{\prime}\left(\bar{\sigma}_{s} A_{s}-\bar{\sigma}_{s c} \cdot A_{s}\right)\right]==\frac{1,57}{1,480 \cdot 10}(-1,48 \cdot 10 \cdot 1,5-40 \cdot 1,57+25 \cdot 1,57)=1,35 \mathrm{~cm}^{3} \\
& D_{c}=\frac{\partial \bar{M}_{u l t}}{\partial \sigma_{c}}=\frac{0,5}{\bar{\sigma}_{c}^{2} \cdot b}\left(\bar{\sigma}_{s} A_{s}-\bar{\sigma}_{s c} \cdot A_{s}^{\prime}\right)^{2}=0, \frac{5}{1,48^{2}} \cdot 10(40 \cdot 1,57-25 \cdot 1,57)^{2}==12,66 \mathrm{~cm}^{3}
\end{aligned}
$$

Визначаємо стандарт граничного моменту

$$
\widehat{M}_{u l t}=\sqrt{\left(D_{c} \hat{\sigma}_{c}\right)^{2}+\left(D_{c} \hat{\sigma}_{S}\right)^{2}+\left(D_{s c} \hat{\sigma}_{S C}\right)^{2}}==\sqrt{(12,66 \cdot 0,199)+(20,27 \cdot 1,744)+(1,35 \cdot 1,09)}=35,47 \mathrm{KHCM}=0,35 \mathrm{skM}
$$

3. Імовірність відмови балки. Обчислюємо характеристику безпеки балки:

$$
\beta=\frac{\bar{M}_{u l t}-M_{u}}{M_{u l t}}=\frac{8,57-7,6}{0}, 35=2,77
$$

Імовірність відмови балки приймаємо в залежності від коефіцієнта $\beta$ за табл. Д.2 [10]

$$
Q(\beta)=4.972 \cdot 10^{-4}
$$

Надійність або безвідмовна робота розглянутої балки

$P(\beta)=0,5+\boldsymbol{\Phi}(\beta)=0,5+0,4972=0,9972$.
Як бачимо із отриманих результатів, надійність випробовуваних балок за дії малоциклових знакозмінних навантажень досить висока.

Висновки. За результатами аналізу експериментально-теоретичних досліджень роботи і напружено-деформованого стану залізобетонних балок, що зазнають дії малоциклових повторних i знакозмінних навантажень визначено оцінку надійності балок при випробуванні вказаних навантажень. Слід зазначити, що надійність роботи таких конструкцій в процесі експлуатації буде забезпечена. 


\section{Список використаних джерел}

1. Райзер, В. Д. Расчет и нормирование надежности строительных конструкций [Текст] / В. Д. Райзер. - М.: Стройиздат, 1995. - 348 с. $-384 \mathrm{c}$.

2. Райзер, В. Д. Теория надежности сооружений [Текст] / В. Д. Райзер. - М.: АСВ, 2010.

3. Перельмутер, А. В. Избранные проблемы надежности и безопасности строительных конструкций [Текст] / А. В. Перельмутер. - 3-е изд. перераб. и доп. - М.: АСВ, 2007. - 256 с.

4. Перельмутер, А. В. Об оценке уязвимости строительных конструкций [Текст] / А.В. Перельмутер, С.Ф. Печугин // Инженерно-строительный журнал. - С.Пб., 2014. №5(59). - C. 5-14.

5. Перельмутер, А. В. Новые направления в анализе надежности строительных конструкций [Текст]: сб. статей / А. В. Перельмутер, С. Ф. Пичугин. - Саарбрюккен, Германия: Изд-во LAP Lambert Academic Publishing, 2014. - 112 c.

6. Пичугин, С. Ф. Оценка надежности статически неопределимых конструкций [Текст] / С.Ф. Пичугин, В.А. Пашинский // Вопросы надежности железобетонных конструкций. Куйбышев, 1977. - С. $72-76$.

7. Пичугин, С. Ф. Об одной оценке надежности статически неопределимых контрукций [Текст] / С.Ф. Пичугин, А.В. Семко // Надежность строительных конструкций: межвуз. сб. науч. трудов. - Куйбышев, 1990. - С. 124-126.

8. Пічугін, С. Ф. Надійність технічних систем [Текст]: навч. посібник / С.Ф. Пічугін. Полтава: ПолтДТУ, 2000. - 157 с.

9. Пичугин, С. Ф. Оценка надежности железобетонных балок с углепластиковым внешним армированием [Текст] / С. Ф. Пичугин // Строительство, материаловедение, машиностроение: сб. науч. трудов. - Днепропетровск: ГВУЗ «ПГАСА», 2014. - Вып. 77. - С. 153-157.

10. Пічугін, С. Ф. Розрахунок надійності будівельних конструкцій [Текст]: монографія / С. Ф. Пічугін. - Полтава: ТОВ «АСМГ», 2016. - 520 с.

11. Кінаш, Р. І. Методи нормування тимчасових навантажень та оцінювання надійності будівельних конструкцій за умов неповної інформації [Текст]: автореф. дис... д-ра техн. наук / Р.І. Кінаш. - К.: КНУБА, 2000. - 32 с.

12. Усаковський, С. Б. С какой точностью вести расчеты прочности сооружений [Текст] / С.Б. Усаковский. - К.: КНУСА, 2005. - 160 с.

13. https://www.scopus.com/authid/detail.uri?authorId=7006743267

14. ДБН В.2.6-98:2009. Конструкції будинків і споруд. Бетонні та залізобетонні конструкції. Оновні положення [Текст]: [чинні від 01.06.11]. - К.: Мінрегіонбуд України, 2011. $-71 \mathrm{c}$.

15. ДСТУ Б.В.2.6.-156. Конструкції будинків і споруд. Бетонні та залізобетонні конструкції з важкого бетону. Правила проектування [Текст]. - К.: Мінрегіонбуд України, 2010. $-123 \mathrm{c}$.

16. ДБН В.1.2.-14-2009. Загальні принципи забезпечення надійності та конструктивної безпеки будівель, споруд, будівельних конструкцій та основ [Текст]. - К.: Мінрегіонбуд України, 2009. - 30 c.

Масюк Григорій Харитонович, канд. техн. наук, професор кафедри промислового, цивільного будівництва та інженерних споруд Національного університету водного господарства та природокористування, м. Рівне.

Тел. (068) 0024720. E-mail: g.h.masyuk@nuwm.edu.ua.

Masyuk Grigoriy Kharitonovich, Candidate of Technical Sciences, Professor of the Chair of Promising, Civil Liberties and Natural Resources of the National University of Water Governance, Nature Reserve, Rivne. Tel. (068) 0024720.

E-mail: g.h.masyuk@nuwm.edu.ua.

Стаття прийнята 24.05.2017 p. 